\title{
Neuroendocrine islet cell tumour producing gastrin and ACTH in a patient with calcifying chronic pancreatitis
}

\author{
M C ALLISON, C C RENFREW, W J S WEBB, \\ $M$ E CHAPPELL, AND R E POUNDER
}

From the Academic Departments of Medicine and Histopathology, Royal Free Hospital School of Medicine, London

SUMMARY A patient with a calcifying chronic pancreatitis was found to have a neuroendocrine islet cell tumour (a previously unreported association). The tumour secreted both gastrin and ACTH leading to clinical manifestations of both the Zollinger-Ellison syndrome and Cushing's syndrome.

The Zollinger-Ellison syndrome is usually caused by a single islet cell tumour in an otherwise normal pancreas. It may also be seen rarely in association with the autosomal dominant syndrome, multiple endocrine neoplasia type I. The Zollinger-Ellison syndrome may also be caused by gastrin secreting primary tumours in the antral or duodenal mucosa, or other sites. ${ }^{1}$ Approximately two-thirds of solitary gastrin producing islet cell tumours exhibit malignant behaviour, with hepatic metastases being found by arteriography or computed axial tomography (CAT) at the time of diagnosis in about $25 \%$ of patients. ${ }^{2}$

Gastrin producing islet cell tumours may secrete more than one hormone. High concentrations of insulin, glucagon, ACTH, human chorionic gonadotrophin (HCG), calcitonin and other hormones, have been reported in association with the Zollinger-Ellison syndrome. ${ }^{1}$ Clinical manifestations arising from secretion of these other substances may occur either simultaneously or at a different time from the symptoms of the ZollingerEllison syndrome. ${ }^{1}$

\section{Case report}

A 67 year old retired businessman presented with abdominal pain, weight loss, and diarrhoea. He admitted to a daily alcohol intake of $80-100 \mathrm{~g}$ for at

Address for correspondence: Dr M C Allison, Academic Department of Medicine, Royal Free Hospital, Pond Street, London NW3 2QG.

Received for publication 8 June 1984 least 20 years. He was found to have steatorrhoea and a plain abdominal radiograph showed pancreatic calcification. Endoscopy revealed multiple small ulcers in the first and second parts of the duodenum. An endoscopic retrograde pancreatogram showed the characteristic ductal changes of chronic pancreatitis. He was treated with cimetidine $1 \mathrm{~g} /$ day and pancreatic enzyme supplements, and a low fat diet was recommended.

His symptoms settled but six months later, despite continuing full dose cimetidine, he had a haematemesis and was again found to have multiple small duodenal ulcers. The fasting plasma gastrin concentration was $1100 \mathrm{pmol} / \mathrm{l}$ (normal $40 \mathrm{pmol} / \mathrm{l}$ ), rising paradoxically to $1600 \mathrm{pmol} / 120$ minutes after a bolus of intravenous $\mathrm{GIH}$ secretin $2 \mathrm{U} / \mathrm{kg}$ body weight. Plasma gastrin concentration was measured by radioimmunoassay in Professor S R Bloom's laboratory at Hammersmith Hospital, using antibody GAS 179 . Cimetidine was stopped for 12 hours, and a pentagastrin test showed a basal acid output of $35.7 \mathrm{mmol} / \mathrm{h}$ with a peak acid output of $51.3 \mathrm{mmol} / \mathrm{h}$.

The Zollinger-Ellison syndrome was diagnosed and the patient was initially treated with ranitidine $150 \mathrm{mg}$ bd. He was considered unfit for major surgery, so localisation of the tumour by portal venous sampling was not attempted. Follow up endoscopy showed that the duodenal ulcers had not healed, hence the dose of ranitidine was increased to $150 \mathrm{mg}$ tds and pirenzepine $50 \mathrm{mg}$ bd added. A repeat pentagastrin test, while receiving this regimen, confirmed a satisfactory decrease of acid 
output (basal $10.0 \mathrm{mmol} / \mathrm{h}$, peak $20.9 \mathrm{mmol} / \mathrm{h}$ ).

Four months later he was admitted with a short history of progressive weakness and ankle oedema. He was found to have a high blood glucose $(27.2$ $\mathrm{mmol} / \mathrm{l}$ ) and a profound hypokalaemia (plasma $\mathrm{K}^{+}$ $1.6 \mathrm{mmol} / \mathrm{l})$. Investigations showed these abnormalities to be due to Cushing's syndrome. The plasma cortisol was $1500 \mathrm{nmol} / \mathrm{l} 12$ hours after $2 \mathrm{mg}$ oral dexamethasone (normal: a fall to at least $70 \%$ below baseline, to approximately $140 \mathrm{nmol} / \mathrm{l}$ ). A CAT scan showed multiple liver metastases and bilateral adrenal hyperplasia; the pancreas was calcified but no primary tumour was observed (Figure). An extremely raised plasma ACTH concentration of $447 \mathrm{ng} / \mathrm{l}$ (normal range 10-80 ng/l, measured by the Supraregional Assay Service using a radioimmunoassay at St Bartholomew's Hospital, London) suggested ectopic ACTH production. A liver biopsy confirmed well circumscribed metastatic tumour deposits with small hyperchromatic cells, compatible with a neuroendocrine origin.

After resuscitation with intravenous potassium chloride infusions $(160 \mathrm{mmol} / \mathrm{day})$ and insulin to control the diabetes, he was treated with aminoglutethimide to block adrenal over production of cortisol. This was followed by chemotherapy with VP16 and chlorambucil. After two weeks steady improvement, with the hypokalaemia controlled by oral potassium syrup $(80 \mathrm{mmol} / \mathrm{day}$; Kay-Cee-L, Geistlich Sons Ltd), he died suddenly.

A necropsy revealed multiple superficial gastric ulcers and also deeper duodenal and jejunal ulcers. Two jejunal ulcers had perforated leading to peritonitis, the immediate cause of death. A tumour $3 \mathrm{~cm}$ in diameter was identified in the head of the pancreas, surrounding but not invading the common bile duct. Chronic pancreatitis with calcification,

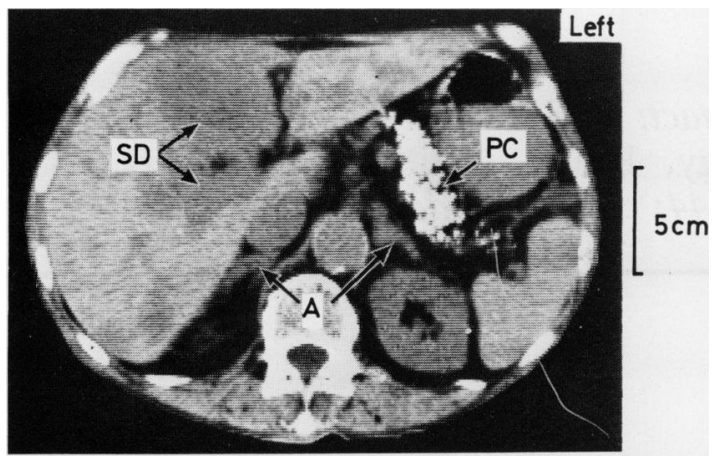

Figure CAT'scan showing dense pancreatic calcification $(P C)$, the liver infiltrated with low attenuation secondary deposits $(S D)$, and bilateral adrenal hyperplasia $(A)$. fibrosis and atrophy of acini was confirmed. There were multiple tumour deposits in the liver and bilateral adrenal hyperplasia. There was no evidence of other endocrine neoplasia. Immunoperoxidase staining and electron microscopy showed gastrin, ACTH, and HCG containing granules within the primary tumour ( Dr J M Polak, Department of Histochemistry, Royal Postgraduate Medical School, London).

\section{Discussion}

To our knowledge this is the first reported case of a malignant neuroendocrine islet cell tumour associated with calcifying chronic pancreatitis. We attribute this patient's chronic pancreatitis to a heavy alcohol intake over many years. Uncertainty remains as to either the malignant potential of chronic pancreatitis or any association of a heavy alcohol intake with pancreatic tumours. In a retrospective study from New Orleans, ${ }^{3} 65 \%$ of 85 patients with pancreatic carcinoma were said to have had a moderate to heavy alcohol intake over several years. The diagnosis of chronic pancreatitis, however, had been made in only two of these patients before the carcinoma was found and there have been few other case reports of pancreatic carcinoma found in association with chronic pancreatitis. $^{3-5}$

There are six other well documented reports of patients with pancreatic tumours secreting both gastrin and ACTH. ${ }^{6-11}$ Two of these tumours also produced glucagon and two secreted melanocyte stimulating hormone. It is likely that the tumour in our patient also secreted a third hormone (HCG) in view of the positive immunoperoxidase staining for HCG. One report ${ }^{12}$ suggests that the finding of HCG in the urine indicates a poor prognosis for patients with a gastrin-secreting tumour.

\section{References}

1 McCarthy DM. Zollinger-Ellison syndrome. Ann Rev Med 1982; 33: 197-215.

2 Doppman JL. Tumour localisation. Zollinger Ellison syndrome: current concepts and management. Ann Intern Med 1983; 98: 59-75.

3 Burch GE, Ansari A. Chronic alcoholism and carcinoma of the pancreas. Arch Intern Med 1968; 122: 273-5.

4 Levison DA. Carcinoma of the pancreas. J Pathol 1979; 129: 203-33.

5 Robinson A, Scott J, Rosenfield DD. The occurrence of carcinoma of the pancreas in chronic pancreatitis. Radiology 1968; 94: 289-90. 
6 Law DH, Liddle GW, Scott HW Jnr, et al. Ectopic production of multiple hormones (ACTH, MSH and gastrin) by a single malignant tumour. $N$ Engl $J$ Med 1965; 273: 292-6.

7 Geokas MC, Dinan JJ, Beck IT. Islet cell carcinoma (Zollinger-Ellison Sydrome) with fulminating adenocortical hyperfunction and hypokalaemia. Can Med Assoc J 1965; 93: 137-43.

8 O’Neal LW, Kipnis PM, Luse SA et al. Secretion of various substances by ACTH-secreting tumours. Cancer 1968; 21: 1219-32.

9 Belchetz PG, Brown CL, Makin HL et al. ACTH, glucagon and gastrin production by a pancreatic islet cell tumour and its treatment. C/n Endocrinol 1973; 2: 307-16.

10 Kyriakides GK, Silvis SE, Ahmed M, Vennes JA, Vogel SB. Gastrinoma in association with common bile duct obstruction and ectopic ACTH. Am J Surg 1979; 137: $800-2$.

11 Asa SL, Kovocs K, Killinger DW, Marcon N, Platts M. Pancreatic islet cell carcinoma producing gastrin, ACTH, alpha-endorphin somatostatin and calcitonin. Am J Gastroenterol 1980; 74: 30-5.

12 Stabile BE, Brownstein GD, Passaro E. Serum gastrin and human chronionic gonadotrophin in the ZollingerEllison syndrome. Arch Surg 1980; 115: 1090-5.

\section{Forthcoming Scientific Meetings of the British Society of Gastroenterology}

Newcastle-upon-Tyne 18-20 September 1985

Lancaster 9-11 April 1986

Cardiff 24-26 September 1986

London 15-18 September 1987

For details of registration please contact: The Administrative Secretary, British Society of Gastroenterology, Rayne Institute, 5 University Street, London, WC1E 66JJ. Tel: (44: country code) 01-387-3534. 